\title{
The Relationship of Interest in Majors and Confidence with Students' Career Planning
}

\author{
Fitri Ningsih ${ }^{1}$, Daharnis ${ }^{2}$ \\ ${ }^{1}$ Universitas Negeri padang \\ ${ }^{*}$ Corresponding author, e-mail: fitriningsih229@gamil.com
}

\begin{abstract}
One of the factors that influence career planning is interest in majors and selfconfidence. This study aims to analyze the relationship between interest in majors and self-confidence with career planning. Methods This research uses a descriptive correlational quantitative method. The research population was the XI grade students of SMK Negeri 3 Padang as many as 246 students and the research sample amounted to 153 students. Sampling using proportional random sampling technique. The instrument used is a Likert Scale model. The research data were analyzed by simple regression and multiple regression. The results of this study indicate that, in general, interest in majors is in the high category, self-confidence is in the high category, student career planning is in the high category, there is a significant relationship between interest in majors and student career planning, there is a significant relationship between trust There is a significant relationship between interest in majors and self-confidence with students' career planning.
\end{abstract}

Keywords: Interest in Department, Self Confidence, Career Planning

How to Cite: Ningsih, F., Daharnis, D. (2021). Relationship of Interest in Majors and Confidence with Career Planning. International Journal of Applied Counseling and Social Sciences, 2 (2): pp. 175-185, DOI: https://doi.org/10.24036/005442ijaccs

This is an open access article distributed under the Creative Commons 4.0 Attribution License, which permits unrestricted use, distribution, and reproduction in any medium, provided the original work is properly cited. @2021 by Author

\section{Introduction}

Talking about career planning, of course, cannot be separated from the discussion regarding what career planning is. Career planning is something that concerns the longterm future that must be planned long ago, planning where one wants to go and what Winkel \& Hastuti, (2010) want to achieve. Simamora (2011) suggests that career planning is a process in which individuals can identify and take steps to achieve career goals. Career planning includes matters relating to information about oneself, considering alternatives and deciding and determining the most suitable career. This process includes three main aspects, namely knowledge and understanding of oneself, 
knowledge and understanding of work, and the use of correct reasoning to be able to make the right career decisions (Walgito, 2005).

Based on the previous description, it can be concluded that career planning is an important thing that must be done by individuals, because with good planning, individuals have a picture related to the career that will be undertaken. Individuals who have career planning will try to understand their potential, understand their environment and career possibilities that suit them. With good planning, individuals indirectly prepare themselves to enter the world of work and career preparation that will make individuals have readiness to enter the world of work after graduation.

Vocational High School is one of the educational facilities that has a very vital role in helping students plan their careers. Law Number 20 of 2003 concerning the National Education System Article 15 states that vocational education is one level of education that prepares students, especially to work in certain fields. In addition, Dikmenjur (2008) also explains the vision and mission of SMK, among others, to create graduates who are ready to work, able to choose a career, able to be competent and develop themselves, have a professional, productive, adaptive and creative attitude and become a middle-level workforce to fill the world's needs. current and future business or industry. The age range of SMK students is between 14-18 years which is the stage of future planning (crystallization) which is cognitive by reviewing oneself and their life situation (Winkel and Hastuti, 2010). This stage plays an important role in a student's career path after graduation. Immaturity in career planning in students can put them in an unpleasant situation or even not get a job (unemployed).

In general, there are two factors that influence career planning. Winkel \& Hastuti (2010) suggested that the factors that influence student career planning are internal factors and external factors. With continuous efforts to improve the quality of SMK through revitalization movements throughout Indonesia, the determining factor that has a greater role is the internal factor that comes from the students themselves. Interest in majors is an internal factor in students which is considered to have a strong relationship with increasing students' career planning abilities. Interest in majors is very important for the future of students. For this reason, the selection of majors must be done carefully, so that there is no wrong choice of majors. The current trend is that many students are not interested in majors and can cause bad things after graduation. After that, bad consequences occurred, namely reluctance to learn and decreased quality and academic achievement because students felt wrong in choosing majors (Supriyo, 2016).

Interest in a major that is described by feeling happy, captivated, and interested in students encourages students' fighting power in achieving or achieving what they want to achieve with regard to their major. Efforts to involve students in studying their majors and show high performance support students' understanding of careers, especially those related to their majors. Therefore, interest in majors is a factor that can predict students' future careers.

Self-confidence is an aspect of personality that contains beliefs about its strengths, abilities and skills. Someone who has self-confidence usually thinks that he is able to do everything he faces (Ghufron \& Rini (2010). The results of research conducted by Komara (2016) prove that there is a significant relationship between self-confidence and 
career planning, thus the higher the confidence, the better the career planning and vice versa if the self-confidence is low, the career planning will also be less good.

However, in reality in the field there are still students who are not ready to enter the world of work and lack a thorough understanding and planning about the majors they choose. This creates a gap between his career planning and the choice of majors he has chosen, so that there is a mismatch between career planning and the choice of majors. Students who do not have high confidence in their abilities will hinder planning their career direction. If this continues, vocational students will have difficulty entering the world of work and pursuing a career direction in the future.

Based on the results of a survey conducted on Monday, January 20, 2020 at SMK Negeri 3 Padang, there were 16 people who experienced a mismatch between their interest in the major they were taking and did not have confidence in their abilities. This means that there are still many students who are immature in their career planning, which can be caused by a mismatch of interest in the department they are occupying and do not believe in their abilities. In addition, based on the results of interviews with BK teachers at SMK Negeri 3 Padang on January 22, 2020, it shows that students' knowledge about the majors they are occupying is still very minimal, students' understanding of future career planning is also still in doubt and the career plans planned by students are very much different from those of students. the major he is currently occupying and there are students who are not yet mature in planning a career that is in accordance with the skill program they are occupying.

Career guidance is an educational effort that helps individuals to achieve the necessary competencies in dealing with career problems. Career guidance is an inseparable part of guidance and counseling, career guidance which not only emphasizes service on the alignment of individual characteristics with the demands of the position or job, but also emphasizes the process of selecting and planning careers in the individual's life journey. Careers require various preparations and careful planning so as to help individuals achieve success and independence for optimal career development. Shiddiqy, Suherman \& Agustin (2019). Career guidance can be defined as an effort made by counselors (professional and trained) to help individuals (in this case students) understand themselves and their environment which is associated with the process of selecting and developing a career to be involved in through a series of guidance and counseling activities (Afdal, 2010). Suya, Syamsu, \& Uman, 2014).

The importance of the role of BK teachers or school counselors in helping vocational students achieve career planning before graduation is one of the efforts that can be made to reduce unemployed vocational graduates. To be able to achieve this, the BK teacher or counselor needs knowledge, understanding of career planning factors and broad skills and has a good career guidance program to assist students in achieving career planning. Therefore, it is necessary to conduct research with the title of the relationship between interest in majors and self-confidence with career planning.

\section{Method}

This research uses descriptive quantitative method. The population of this study were students of class XI SMK Negeri 3 Padang as many as 246 students and the research sample amounted to 153 students. Sampling using proportional random sampling technique. The instrument used is an instrument of interest in majors, self-confidence and career planning with a Likert scale model. Research data were analyzed by simple regression and multiple regression. 


\section{Results and Discussion}

Overall career planning, interest in majors and self-confidence of class XI students at SMK Negeri 3 Padang are in the high category, the details of which can be seen in Tables 1, 2 and 3 as follows.

Tabel 1. Planning of SMK Negeri 3 Padang student (N=153)

\begin{tabular}{llllcrrrrc}
\hline No & \multicolumn{10}{c}{ SKOR } \\
\cline { 2 - 9 } $\mathbf{1}$ & \multicolumn{1}{c}{ Indicator } & Ideal & Max & Min & $\Sigma$ & Mean & $\%$ & Sd & Ket \\
& $\begin{array}{l}\text { Self } \\
\text { Understanding } \\
(8)\end{array}$ & 40 & 40 & 19 & 4628 & 30.24 & 75.62 & 5.26 & $\mathrm{~T}$ \\
$\mathbf{2}$ & $\begin{array}{l}\text { Knowledge of } \\
\text { the word of } \\
\text { work (10) }\end{array}$ & 50 & 50 & 24 & 6097 & 39.85 & 79.69 & 6.55 & $\mathrm{~T}$ \\
$\mathbf{3}$ & $\begin{array}{l}\text { Make Decisions } \\
\text { (6) }\end{array}$ & 30 & 30 & 12 & 3511 & 22.95 & 76.49 & 4.62 & $\mathrm{~T}$ \\
Whole & 120 & 118 & 61 & 14236 & 93.04 & 77.53 & 15.29 & $\mathrm{~T}$ \\
\hline
\end{tabular}

Based on Table 1, it can be seen that the overall picture of career planning for SMK Negeri 3 Padang students is in the high category with an achievement percentage of $77.53 \%$, meaning that SMK 3 Negeri Padang students are able to plan careers, seek information about the world of work and are able to make good career decisions.

Tabel 2. Interest In Major Students SMK Negeri 3 Padang (N=153)

\begin{tabular}{|c|c|c|c|c|c|c|c|c|c|}
\hline \multirow[t]{2}{*}{ No } & \multicolumn{9}{|c|}{ SKOR } \\
\hline & Indicator & Ideal & Max & Min & $\Sigma$ & Mean & $\%$ & $\mathrm{Sd}$ & Ket \\
\hline 1 & Attitude(5) & 25 & 25 & 13 & 2784 & 18.19 & 72.78 & 2.39 & $\mathrm{~T}$ \\
\hline 2 & Preference (6) & 30 & 30 & 13 & 3048 & 19.92 & 66.40 & 3.12 & $S$ \\
\hline 3 & Awarenes (5) & 25 & 25 & 12 & 3160 & 20.65 & 82.61 & 3.30 & $\mathrm{~T}$ \\
\hline 4 & $\begin{array}{l}\text { Feeling happy } \\
\text { (12) }\end{array}$ & 60 & 60 & 28 & 7494 & 48.98 & 81.63 & 7.75 & $\mathrm{~T}$ \\
\hline 5 & $\begin{array}{l}\text { There Is Interest } \\
\text { (4) }\end{array}$ & 20 & 20 & 12 & 2652 & 17.33 & 86.66 & 2.21 & ST \\
\hline \multicolumn{2}{|c|}{ Whole } & 160 & 158 & 91 & 19138 & 125.08 & 78.17 & 15.23 & $\mathrm{~T}$ \\
\hline
\end{tabular}

Based on Table 2, it can be seen that the overall picture of interest in the majors of students of SMK Negeri 3 Padang is in the high category with an achievement percentage of $78.17 \%$, meaning that students of SMK 3 Negeri Padang have an interest in good majors.

Based on Table 3, it can be seen that the overall picture of self-confidence of SMK Negeri 3 Padang students is in the high category with an achievement percentage of $73.69 \%$, meaning that students of SMK Negeri 3 Padang have good self-confidence. 
Tabel 3. Confidence Student SMK Negeri 3 Padang (N=153)

\begin{tabular}{|c|c|c|c|c|c|c|c|c|c|}
\hline \multirow[t]{2}{*}{ No } & \multicolumn{9}{|c|}{ SKOR } \\
\hline & Indicator & Ideal & Max & Min & $\Sigma$ & Mean & $\%$ & $\mathrm{Sd}$ & Ket \\
\hline 1 & $\begin{array}{l}\text { Confident in your } \\
\text { own Ability (8) }\end{array}$ & 40 & 40 & 21 & 4664 & 30.51 & 76.29 & 4.77 & $\mathrm{~T}$ \\
\hline 2 & $\begin{array}{l}\text { Acting } \\
\text { Independently in } \\
\text { Making Decisions } \\
\text { (5) }\end{array}$ & 25 & 25 & 14 & 3173 & 20.73 & 82.95 & 2.69 & $\mathrm{~T}$ \\
\hline 3 & $\begin{array}{l}\text { Have a Positive } \\
\text { Self Concept (6) }\end{array}$ & 30 & 29 & 10 & 2921 & 19.09 & 63.63 & 3.45 & $S$ \\
\hline 4 & $\begin{array}{l}\text { Dare To Express } \\
\text { Opinions (5) }\end{array}$ & 25 & 25 & 8 & 2772 & 18.12 & 72.47 & 3.06 & ST \\
\hline \multicolumn{2}{|c|}{ Whole } & 120 & 115 & 67 & 13530 & 88.43 & 73.69 & 10.39 & $\mathrm{~T}$ \\
\hline
\end{tabular}

The results of the hypothesis test of the relationship between interest in majors and self-confidence with career planning using simple correlation analysis and multiple regression can be seen in Tables 4.5 and 6 .

Table 4. Result of simple correlation test of interest in majorsnwith career planning

\begin{tabular}{lccc}
\hline Variable & $\boldsymbol{R}$ & $\boldsymbol{R}$ Square & Adjusted $\mathrm{R}$ Square \\
\hline $\mathrm{X}_{1}-\mathrm{Y}$ & 0,757 & 0,573 & 0,570 \\
\hline
\end{tabular}

Based on Table 4 above, it can be seen that the correlation value (R) obtained is 0.757 . with a value of $\mathrm{R}$ Square (R2) of 0.573 while the value of the adjusted regression coefficient (Adjusted R Square) of 0.570 . That is, the level of student career planning can be explained by the variable of interest in the major. So it can be concluded that the higher the student's interest in the department, the higher the student's career planning.

Table 5. Simple Correlation Test Results Confidence with Career Planning

\begin{tabular}{cccc}
\hline Variabel & $\boldsymbol{R}$ & $\boldsymbol{R}$ Square & Adjusted $\mathrm{R}$ Square \\
\hline $\mathrm{X}_{2} \mathrm{Y}$ & 0,779 & 0,607 & 0,604 \\
\hline
\end{tabular}

Based on Table 5 above, it can be seen that the correlation value (R) obtained is 0.779 . with a value of $\mathrm{R}$ Square (R2) of 0.607 while the value of the adjusted regression coefficient (Adjusted $\mathrm{R}$ Square) of 0.604 There is a significant relationship between selfconfidence and career planning with a correlation test of $60.4 \%(R=0.779$, AR2 $=0.604$. That is, high and low The achievement of student career planning can be explained by the variable of self-confidence, so it can be concluded that the higher the self-confidence in students, the higher the career planning of students.

Table 6. Results of the Multiple Correlation Test of Interest in Majors and Confidence with Career Planning

\begin{tabular}{lccc}
\hline Variable & $\boldsymbol{R}$ & $\boldsymbol{R}$ Square & Adjusted $\mathrm{R}$ Square \\
\hline $\mathrm{X}_{1}, \mathbf{X}_{2}-\mathrm{Y}$ & 0,831 & 0,690 & 0,686 \\
\hline
\end{tabular}


Based on Table 6 above, it can be seen that the correlation value (R) obtained is 0.831 . with a value of $R$ Square (R2) of 0.690 while the value of the adjusted regression coefficient (Adjusted R Square) of 0.686. There is a significant relationship between interest in majors and self-confidence together with career planning with a correlation test of $68.6 \%(R=0.831$, AR2 $=0.686$. That is, the level of student career planning can be explained by the variable interest in majors and other variables). So that it can be concluded that the higher the interest in the department and the self-confidence that exists in students, the student's career planning also increases

Based on the results of hypothesis testing that has been done that there is a significant relationship between interest in majors and self-confidence with student career planning. That is, the higher the interest in the major and the student's self-confidence, the higher the career planning achieved. The following will explain the discussion for each variable in this study, namely as follows.

\section{Planning Career}

Based on the analysis conducted on the career planning data of class XI students of SMK 3 Negeri Padang, it can be concluded that the overall career planning of students is in the high category. Career planning is a person's efforts that are carried out consciously, planned and intentional to improve the individual's ability to achieve the desired goals. Career planning is not only done on adults, but in this case is done on the need to achieve student development. Students who are able to understand career planning are students who are able to understand their strengths and weaknesses, are able to recognize the environment of life and are able to recognize the scope of work and further studies.

Career planning is so important because it can be used as a guide for students in making decisions about their future careers. Bardick, Bernes, Magnusson \& Witko (2004) explain that career planning is very important during adolescence because individuals begin to explore their abilities, values, interests and opportunities in preparing for a career. to achieve a career. In addition, the importance of career planning for students to assist them in assessing their own abilities and interests, considering alternative career opportunities, setting career goals, and planning practical development activities. The impact obtained illustrates that this activity is able to provide a positive influence for students in formulating career plans (Saputra, Rizal, Noor \& Prasetya, 2020).

Fadli, Alizamar \& Afdal (2017) mention that students in SMK based on the stages of development are in adolescence, the tasks of adolescent career development are: (a) choosing a job that suits their abilities, (b) preparing themselves to have the knowledge and skills to enter a job. the. Future orientation or career is one of the phenomena of cognitive development that occurs in adolescence. Furthermore, Afdal (2018) suggests that career planning in career development is something that is systematic and continuous. Systematic in the sense that career planning has stages that are passed, which are continuous with each other, have a relationship with each other.

The above conditions indicate that students' readiness in planning their careers is very important in career planning, namely as a step for students to get to know the types of further education and the world of work, to be used as relevant references in making career decisions and fulfilling development tasks. Students need to be provided with information about career planning. At this stage it is very important for students to be aware of the 
various options available after completing SMK. Therefore, in order to reach the stage of student career development, there needs to be awareness in students to have career planning starting from self-understanding, exploring career information, setting goals and making decisions, and making steps to achieve career goals. The existence of students' self-awareness about the need to have a mature career will appear interest in developing career planning and carrying out every stage that exists to achieve the desired career goals.

Based on the explanation above, it can be concluded that career planning will help students to achieve their desired career goals, therefore it is necessary to have career planning starting from the education period. In addition, because there are still some students who have poor career planning, this needs special attention from the counseling teacher to help students have better career planning. Thus, the data from this research can be used as a process of analyzing student needs. This needs analysis is then used by the BK teacher as a guide in preparing the BK program. The preparation of programs according to the needs of students is expected to be able to help students to make good career plans and they can be carried out consistently and responsibly.

\section{Interest in the Department}

Based on the results of research data analysis, interest in majors reveals that in general students have an interest in majors that are in the high category. Students in Vocational High Schools (SMK) based on the stages of development are in their teens. Teenagers' interests indicate that planning and preparing for work are their main interests, both for boys and girls. One of the tasks of adolescent development is planning and decision making. Their behavioral profiles include being able to choose one job from a variety of diverse jobs, being able to plan what to do after graduating from school, being able to choose a study program that suits their interests and abilities, being able to make decisions about where to work (Fadli, Alizamar, \& Afdal, 2017).

Individual development in which one part of it is the development of career direction requires individuals to be able to achieve optimal development, ideally individuals must be able to master every task and demand that is in the development stage. Adolescent career development must make a decision about the career to be chosen, and plan the career path that will later be occupied. After a person has a career orientation, he will make further plans regarding his career, which is related to the desire to excel and achieve high positions in work (Sofyan, Yusuf \& Daharnis, 2013).

Interest can be defined as a sense of preference and interest in a major. Each individual in choosing a major begins with a sense of interest and the need to develop knowledge. Interest will encourage someone to take an action and participate in things that interest him (Sulistyawati, Herwati \& Julianto, 2017)

\section{Confidence}

Based on the analysis conducted on self-confidence data, it can be concluded that in general, confidence is in the high category. Confidence can change a person, from those who are not brave with their self-confidence, someone is more courageous and confident that they are able to face or do something. Self-confidence is the effect of how individuals feel, believe and know. Individuals who have negative feelings towards themselves, have weak confidence in their abilities and have less accurate knowledge of their capacities. Conversely, individuals who have good self-confidence, they have positive feelings about themselves, 
have strong beliefs about themselves and have accurate knowledge of their abilities. Individuals who have good self-confidence are not people who only feel capable but are people who know that they are capable based on experience and calculations.

Individuals who have high confidence fulfill the five aspects mentioned above, Aldi (2020) explains that a person's self-confidence can increase expectations for achievement. With high self-confidence will increase the abilities possessed by individuals, including in communicating. Furthermore, Pradita (2014) suggests that someone who does not have selfconfidence, there will be many problems that arise, because self-confidence is an aspect of a person's personality that functions to actualize their potential, therefore individuals with low self-confidence will be hampered from optimizing their abilities. which he has.

The symptoms of lack of self-confidence in individuals can be seen in various behaviors. The results of Fatchurahman \& Pratikto's research (2012) suggest that self-confidence in adolescents is related to negative behavior or delinquency caused, which will make it difficult for adolescents to interact and develop positive judgments both towards themselves and the environment they face. There are various kinds of behavior that reflect individuals having symptoms of lack of self-confidence. Hakim (2005) explained that behavioral symptoms that do not have good self-confidence that appear in the educational environment are: (1) afraid to face tests, (2) inferior, (3) not daring to ask questions and express opinions, (4) nervous when appearing in front of students. class, (5) excessive shyness arises, (6) grows timid, (7) often cheats when dealing with tests, (8) is easily anxious in dealing with various situations, (9) misbehaves in dealing with the opposite sex and (10) brawls and riots.

Based on the explanation above, it can be understood that if students do not have high self-confidence, it will have an impact on negative behavior. Based on the results of the study, the confidence of students at SMK Negeri 3 Padang is in the high category, it is necessary to maintain the self-confidence that already exists in students and increase student self-confidence which is still low through the role of BK teachers and the whole environment to help students increase student confidence. , so that they can optimize themselves and are able to plan a career.

\section{Relationship of Interest in Majors with Career Planning}

The results showed that there was a significant relationship between interest in majors and students' career planning. This means that interest in majors is one of the factors related to student career planning. This finding was obtained based on data analysis that the correlation test of interest in majors with student career planning was $57.0 \%$, while the rest $(43 \%)$ were explained by other variables. This means that interest in majors is one of the factors related to student career planning. Interest in a major is an individual's interest in an object or action accompanied by attention and feelings of pleasure to do so. Determining the major is important, because it will greatly affect the success of studies and also to get a job (Trisnayadi, 2013).

Based on the explanation above, it can be understood that interest in majors can have a considerable impact on students' career planning, where increasing student interest in majors will help students in planning their careers.

\section{Confidence Relationship with Career Planning}

The results showed that there was a significant relationship between self-confidence and students' career planning. This means that self-confidence is one of the factors related to 
student career planning. This finding was obtained based on data analysis that the correlation test of self-confidence with student career planning was $60.4 \%$, while the rest (39.6\%) was explained by other variables. This means that self-confidence is one of the factors related to student career planning. The results of Komara's research (2016) show that there is a positive relationship between self-confidence and student career planning. This is in accordance with the results of research conducted by researchers that self-confidence is related to career planning. This means that the higher the individual's self-confidence, the better his career planning, on the other hand, if the individual's self-confidence is low, it will result in poor career planning.

The results of the study showing that self-confidence is significantly related to career planning, meaning that self-confidence is one of the factors that influence career planning. In line with the results of Masturina's research (2018), it shows that there is a significant relationship between self-confidence and career planning. Lauster (2006) explains that there are five aspects that affect the individual's self-confidence as follows; (1) belief in self-ability, which means the individual's positive attitude about himself and how the individual understands everything that is in him, is able to develop his strengths and is able to understand his weaknesses, (2) optimistic, namely a positive attitude that always has a good view in dealing with everything, Individuals who have an optimistic attitude are not afraid of failure and are able to rise and learn from previous failures, (3) objective, namely the individual's attitude to assessing everything according to the truth that exists, (4) being responsible, namely the individual's willingness to bear everything that has become consequences for what has been done, both good and bad consequences, and (5) rational and realistic, namely the ability to analyze problems or events using a reasonable mind.

\section{Relationship of Interest in Majors and Confidence with Career Planning}

The results showed that there was a significant relationship between interest in majors and self-confidence with students' career planning. This means that interest in majors and self-confidence is one of the factors related to student career planning. This finding was obtained based on data analysis that the correlation test of interest in majors and selfconfidence with student career planning was $68.6 \%$, while the rest $(31.4 \%)$ was explained by other variables. This means that interest in majors and self-confidence is one of the factors related to student career planning.

Career planning tries to help individuals to understand their personal conditions (traits or personality, talents and interests as well as their strengths and weaknesses) and provides an overview of various fields of career interest in psychology. Through career planning training, individuals are invited to think realistically by comparing their personal characteristics with the characteristics of each career interest field with the aim that the individual concerned is able to optimally direct his career by choosing a career interest field that matches his interests and abilities. The essential processes of effective career planning are initiative, exploration, decision making, preparation and implementation. To start a plan requires the initiative to move someone to explore a particular career, after that making decisions about what kind of career will be undertaken (Nasution, 2019). Therefore, interest in majors and self-confidence are included in the determinants of success or failure of students in planning their careers. 


\section{Conclusion}

From the results and discussion of the research, it can be concluded that there is a significant relationship between interest in majors and career planning. That is, the level of student career planning can be explained by the variable of interest in the major; the higher the interest in the majors that exist in students, the student's career planning also increases. There is a significant relationship between self-confidence and career planning. That is, the high and low achievement of students' career planning can be explained by the variable of self-confidence, it can be concluded that the higher the self-confidence that exists in students, then the career planning of students also increases. There is a significant relationship between interest in majors and self-confidence together with career planning. That is, the level of student career planning can be explained by the variable of interest in the major and the variable of self-confidence, it can be concluded that the higher the interest in the major and the self-confidence of the student, the higher the student's career planning.

\section{References}

Afdal, A. 2018. Model bimbingan karir kolaboratif dalam memantapkan perencanaan karir siswa SMA. Disertasi.

Afdal, A., Suya, M., Syamsu, S., \& Uman, U. 2014. Bimbingan karir kolaboratif dalam pemantapan perencanaan karir siswa SMA. Jurnal Konseling dan Pendidikan, 2(3), 1-7.

Aldi, A. H. 2020. Kontribusi antara kepercayaan diri dengan interaksi sosial terhadap presentasi diri pada peserta duta FKIP ULM tahun 2018. Jurnal Pelayanan Bimbingan dan Konseling, 3(2), 132-138.

Bardick, A. D., Bernes, K. B., Magnusson, K. C., \& W. K. D. 2004. Junior high career planning: what students want. ,. Canadian Journal of Counseling, 38(2), 104-117.

Dikmenjur. 2008. Kurikulum SMK. Jakarta: Direktorat Pembinaan Sekolah Menengah Kejuruan.

Fadli, R. P., Alizamar, A. 2017. Persepsi siswa tentang kesesuaian perencanaan arah karir berdasarkan pilihan keahlian siswa sekolah menengah kejuruan, 6(2), 74-82.

Fatchurahman, M., \& Pratikto, H. 2012. Kepercayaan diri, kematangan emosi, pola asuh orangtua demokratis dan kenakalan remaja. Jurnal Psikologi

Ghufron dan Rini. 2010. Teori-teori psikologi. Jogjakarta: Ar-Ruzz Media.

Hakim, T. 2005. Mengatasi rasa tidak percaya diri. Jakarta: Puspa Swara.

Komara, I. B. 2016. Hubungan antara Kepercayaan Diri dengan Prestasi Belajar dan Perencanaan Karir Siswa, 5(1), 33-42.

Lauster, P. 2006. Tes kepribadian (Edisi Bahasa). Jakarta: Bumi Aksara.

Masturina, D. 2018. Pengaruh kompetensi diri dan kepercayaan diri terhadap perencanaan karir mahasiswa program studi peternakan Universitas Mulawarman. Psikoborneo, 6(2), 340-350.

Nasution, H. 2019. Perencanaan karir mahasiswa setelah wisuda pascasarjana. Consilium: 
Berkala Kajian Konseling Dan Ilmu Keagamaan, 6 (1), 1.

Pradita. S. (2014). Stop minder dan grogi: saatnya tampil beda dan percaya diri. Yogyakarta: Araska.

Saputra, Rizal, Noor, \& P. 2020. Pelatihan career planning untuk meningkatkan kemampuan mahasiswa dalam merumuskan rencana karier. Jurnal RAP (Riset Aktual Psikologi), 11, $24-34$.

Shiddiqy, A. R., Suherman, U., \& Agustin, M. (2019). Efektivitas bimbingan karier terhadap kematangan karier mahasiswa. Indonesian Journal of Educational Counseling, 3(3), 301311.

Simamora, H. 2011. Manajemen sumber daya manusia. Yogyakarta.: YKPN.

Sofyan, A., Yusuf, A. M., \& Daharnis. (2013). Tingkat aspirasi karir siswa di tinjau dari jenis kelamin, jurusan dan daerah tempat tinggal. Jurnal Konseling dan Pendidikan, 1, 9-27.

Sulistyawati, N. L. G. A., Herwati, N. T., \& Julianto, I. P. (2017). Pengaruh minat, potensi diri, dukungan orang tua, dan kesempatan kerja terhadap keputusan mahasiswa memilih jurusan akuntansi program S1 Universitas Pendidikan Ganesha. E-Journal Ak Universitas Pendidikan Ganesha, 8(2), 1-12.

Supriyo, L. 2016. Kontribusi minat jurusan, kualitas layanan informasi karir, dan pemahaman karir terhadap kemampuan mengambil keputusan karir. Jurnal Bimbingan Konseling, 5(1), 47-54.

Trisnayadi, T. 2013. Bimbingan karier untuk pelajar. Erlangga.

Walgito, B. 2005. Bimbingan dan konseling (studi dan karier). Jogjakarta: CV Andi Offset.

Winkel, W \& Hastuti, S. 2010. Bimbingan dan konseling di institusi pendidikan. Yogyakarta.: Media abadi. 